\title{
Original
}

\section{Development of New Titanium Coating Material (CaTiOz-aC) with Modified Thermal Decomposition Method}

\author{
Noriyuki Nagai $^{1,2)}$, Mika Okauchi ${ }^{1)}$, Andrea Rodriguez ${ }^{1)}$, Mehmet Gunduz ${ }^{1)}$, Hailong Hu${ }^{1)}$, Midori Kubota ${ }^{1)}$ \\ Noriyuki Nagaoka'), Miho Inoue ${ }^{1)}$, Hitoshi Nagatsuka'), Tohru Takagi ${ }^{1,2)}$ and Masaru Akao ${ }^{2)}$ \\ ${ }^{1)}$ Department of Oral Pathology and Medicine, Graduate School of Medicine, Dentistry and Pharmaceutical Sciences, Okayama \\ University, Okayama, Japan \\ 2) Center of Oral Health Science, International Dental Hygienist College in Okayama, Motoyama Gakuin, Okayama, Japan
}

(Accepted for publication, May 12, 2008)

\begin{abstract}
We developed a novel method for titanium coating material using modified thermal decomposition technique, specifically focusing on presence of $\mathrm{CaTiO}_{3}$ and carbon $\mathrm{C}$. Two layers of thin film coating composed of $\mathrm{CaTiO}_{3}$-amorphous carbon compound $\left(\mathrm{CaTiO}_{3}-\mathrm{aC}\right)$ and hydroxyapatite $(\mathrm{HA})$ were generated on titanium surface. In this method, ratios of $\mathrm{Ca} / \mathrm{P}$ as well as $\mathrm{Ca} / \mathrm{Ti}$, sintering temperature and sintering velocity were carefully planned. Within crystal structure of $\mathrm{CaTiO}_{3}$ granules, 4 atomic $\%$ of carbon in amorphous state was included. By our method, inclusion of carbon in HA suggested formation of carbonate apatite. Regarding with attachment-detachment experiment at titanium surface, adhesion strength was 2.5 times stronger in $\mathrm{CaTiO}_{3}-$ $\mathrm{aC} / \mathrm{HA}$ coating substrate as compared to HA only coating material. Results of the novel developed modified thermal decomposition method suggested that the 2 layers biomaterial composed of $\mathrm{CaTiO}_{3}-\mathrm{aC}(0.6 \mu \mathrm{m})$ and carbonate apatite-included HA $(2.4 \mu \mathrm{m})$ can be used as a coating material on titanium surface.
\end{abstract}

Key words: Biomaterial, Titanium, Carbon, HA, Coating material, $\mathrm{CaTiO}_{3-\mathrm{a}} \mathrm{C}$

\section{Introduction}

Titanium implant has now been used in the clinics after reforming its surface with several methods such as blasting. Although titanium implant possesses excellent mechanical strength and biocompatibility, affinity to living bone is very low due to its bioinert feauture ${ }^{1)}$. On the other hand, hydroxyapatite (HA) has excellent bone conductivity with osteogenic tissue, and thus has been widely used as a filling material ${ }^{2-4}$. Thus HA is generally used as a coating material to improve bone conductivity of metal materials such as titanium and its alloys, stainless steel, and CoCr-Mo alloys ${ }^{1,5,6}$. Plasma-sprayed HA coating of titanium implant is one of the most commonly used methods in the clinics ${ }^{7-10)}$. However, there are many shortcomings of this method. The plasma method is performed at high surface temperature $\left(1200^{\circ} \mathrm{C}\right)$, and coating film is thick $(50 \mu \mathrm{m})$ and is easy to detach ${ }^{6,7,11,12)}$. It has also been known that bone bonding ability decreases in coatings performed with this method. Moreover, HA coating formed by plasma method consists of $\alpha-\mathrm{TCP}$, and its chemical bonding ability

Corresponding author:Noriyuki Nagai DDS.DS.phD. Department of Oral Pathology and Medicine, Graduate School of Medicine, Dentistry and Pharmaceutical Sciences, Okayama University, 2-5-1 Shikatacho, Okayama 700-8525, Japan.Tel: +81-86-235-6652, Fax: +81-86-235-6654, E-mail:nori@md.okayama-u.ac.jp with titanium is weak. There are also concerns of resorption in biological environment ${ }^{9,13,14)}$.

To solve these problems, development of a different method other than direct plasma-sprayed HA coating to implant substrate is necessary. Conditions for development of such a method include: (1) a thin HA layer without $\alpha$-TCP, and similar level of crystal structure and components with living body from a perspective of biological affinity, (2) necessity of development of a material with possible thinnest but strongest ability of adhesion at interface between HA and titanium substrate, and (3) this adhesive material should have biological affinity with long-term bioactivity in living bone.

Herein, we report development of a film-like new titanium coating material containing $\mathrm{CaTiO}_{3}$ and carbon with modified thermal decomposition method.

Ukegawa performed plasma coating of HA at titanium implant surface and examined bone bonding ability ${ }^{10}$. Although presence of perovskite $\left(\mathrm{CaTiO}_{3}\right)$-like substrate was reported as an adhesive interposition material (between $\mathrm{TiO}_{2}-\mathrm{HA}$ ), structure as well as its involvement in adhesion was unknown at the time.

Preparation of perovskite $\left(\mathrm{CaTiO}_{3}\right)$ is normally made by dry method. Thus it could not be synthesized other than powder 
particles, and its film coating type was not possible. Zhou and $\mathrm{Akao}^{6)}$ have reported excellent bone-conductivity of HA coating by thermal decomposition method using 2 layers of coating method composed of HA and a film compound, which consists of perovskite $\left(\mathrm{CaTiO}_{3}\right)$ as a main component. We focused carbon in organic solvent of the liquid used in thermal decomposition method. This carbon has been known to improve wetness of metal ${ }^{15)}$. Thus we developed modified thermal decomposition method, considering that by providing existence of carbon in addition to $\mathrm{CaTiO}_{3}$ within crystal structure of adhesive material, adhesive strength would increase. We named our new material as $\mathrm{CaTiO}_{3}$-amorphous carbon $(\mathrm{aC})$ compound.

In this study, we used $\mathrm{CaTiO}_{3}-\mathrm{aC}$ as coating material and examined adhesive strength with titanium.

\section{Material and Methods \\ 1. Preparation of $\mathrm{CaTiO}_{3}-\mathrm{CC}$ as well as coating solution}

Highly pure $\mathrm{CaCO}_{3}$ was heated at $1050{ }^{\circ} \mathrm{C}$ in normal air for 2 hours, and $\mathrm{CaO}$ was obtained.

28.8 gram of 2-ethyl hexanic acid $\left(\mathrm{CH}_{3}\left(\mathrm{CH}_{2}\right)_{3} \mathrm{CH}\left(\mathrm{C}_{2} \mathrm{H}_{5}\right)\right.$ $\mathrm{COOH}$ ) was put into $100 \mathrm{ml}$ conical flask. While it is being heated from $100{ }^{\circ} \mathrm{C}$ to $120^{\circ} \mathrm{C}, 3.36$ gram of this calcium oxide powder was gradually added and 2-ethyl hexane calcium $\left(\left[\mathrm{CH}_{3}\left(\mathrm{CH}_{2}\right)\right.\right.$ $\left.\left.{ }_{3} \mathrm{CH}\left(\mathrm{C}_{2} \mathrm{H}_{5}\right) \mathrm{COO}\right]_{2} \mathrm{Ca}\right)$ solution was prepared.

After cooling, it was dissolved by adding 48 gram of 1-butanol $\left(\mathrm{CH}_{3}\left(\mathrm{CH}_{2}\right)_{3} \mathrm{OH}\right)$, and followed by addition of 170 gram of titanium tetraisopropoxide ( $\left.\mathrm{Ti}\left[\mathrm{OCH}\left(\mathrm{CH}_{3}\right)_{2}\right]\right)$. Then well stirring was performed, and about $110 \mathrm{ml}$ of stock application solution was prepared. The stock solution had a specific gravity of 0.92 , and was clear, yellowish brown viscose material. $\mathrm{CaTiO}_{3}-\mathrm{aC}$ application solution was obtained by diluting the stock solution 3 times (mass ratio) with 2-propanol $\left(\mathrm{CH}_{3} \mathrm{CH}(\mathrm{OH}) \mathrm{CH}_{3}\right)$.

For HA solution, it was prepared following the similar method mentioned above. 2-ethyl hexane calcium ( $\left[\mathrm{CH}_{3}\left(\mathrm{CH}_{2}\right)_{3} \mathrm{CH}\left(\mathrm{C}_{2} \mathrm{H}_{5}\right)\right.$ $\left.\mathrm{COO}]_{2} \mathrm{Ca}\right)$ was dissolved in $42 \mathrm{~g}$ of 1-butanol $\left(\mathrm{CH}_{3}\left(\mathrm{CH}_{2}\right)_{3} \mathrm{OH}\right)$. Then 10.7 gram of bis (2-ethylhexyl) phosphate $\left(\left[\mathrm{CH}_{3}\left(\mathrm{CH}_{2}\right)_{3} \mathrm{CH}\right.\right.$ $\left.\left.\left(\mathrm{C}_{2} \mathrm{H}_{5}\right) \mathrm{CH}_{2} \mathrm{O}\right]_{2} \mathrm{POOH}\right)$ and 2.9 gram of distilled water were added, followed by well stirring. Finally $100 \mathrm{ml}$ of the solution was prepared. This solution was clear, viscose liquid and had a specific gravity of 0.89 . Hydroxyapatite (HA) application solution was obtained by diluting the stock solution 2 times with 2-propanol $\left(\mathrm{CH}_{3} \mathrm{CH}(\mathrm{OH}) \mathrm{CH}_{3}\right)$.

\section{Preparation and analysis of test pieces of each titanium coating plate}

Etching of JIS2 type titanium plate with $0.7 \mathrm{~mm}$ thickness and $35 \mathrm{~mm}$ angle was performed by boiling it in $6 \mathrm{~N} \mathrm{HCl}$ solution for 15 minutes. Then it was rinsed one time in tap water and 3 times in distilled water, and then was dried at $60^{\circ} \mathrm{C}$.

The titanium plate was soaked in each of the above $\mathrm{C}$ and HA application solutions for 5 minutes. The materials were then slowly pulled up in vertical direction, and dried 10 minutes at room temperature and 20 minutes at $110^{\circ} \mathrm{C}$. The material was then quickly heated at $650^{\circ} \mathrm{C}$ in a firing furnace for 10 minutes, followed by rapid cooling.

\section{Basic handling of the coating method:}

1 layer coating method with $\mathrm{CaTiO}_{3}-\mathrm{aC}$ is repeated 3 times as mentioned in method 2 (including soaking the titanium plate in $\mathrm{CaTiO}_{3}-\mathrm{aC}$ application solution, firing as well as rapid cooling).

1 layer coating method with HA is repeated 10 times as mentioned in method 2 (including soaking the titanium plate in HA application solution, firing as well as rapid cooling).

\section{(1) Preparation and examination of the powder for carbon analysis}

Test piece of 1 layer coating with $\mathrm{CaTiO}_{3}-\mathrm{aC}$ was prepared, and distribution state of carbon within $\mathrm{CaTiO}_{3}-\mathrm{aC}$ was observed by TEM as well as EF-TEM (Energy Filtered TEM). TEM observation sample was prepared as follows: Surface of the sample was shaved by scratching with a diamond pen. Shaved powder particles were dispersed in ethanol, followed by dropping on micro grid (a grid attached to a plastic film with carbon-coated micro hole) and drying. For EF-TEM analysis, JEM-3010 (speed voltage $300 \mathrm{kV}$ ) was used (JEOL co. 1td., Tokyo, Japan).

Using the same material, EELS (Electron Energy-Loss Spectroscopy) analysis was performed. This method provides element analysis of the sample through passing of an electronic energy spectrum. For EELS analysis, JEM-2200FS was used (JEOL co. 1td., Tokyo, Japan).

\section{(2) Measurement and analysis of the layer thickness as well as cross-sectional observation}

After preparation of test piece of 1 layer coating with $\mathrm{CaTiO}_{3}-$ $\mathrm{aC}, 1$ layer of HA coating was performed on it. Then these 2 types of coating $\left(\mathrm{CaTiO}_{3}-\mathrm{aC} / \mathrm{HA}-\mathrm{CaTiO}_{3}-\mathrm{aC} / \mathrm{HA}\right)$ were repeated, and a test piece of 4 layers coating was prepared (hereafter called as test piece of 4 layers coating). For performing cross-sectional SEM analysis of the 4 layers coating test piece, it was processed with cross-sectional polisher (JEOL SM-09010). Then it was observed and analyzed with SEM (JEOL JSM-7000F)-EDX(ED2300F). And taking mass increase and theoretical density of the piece into account $\left(\mathrm{CaTiO}_{3}: 4.04 \mathrm{~g} / \mathrm{cm}^{3}, \mathrm{HA}: 3.16 \mathrm{~g} / \mathrm{cm}^{3}\right)$, thickness of each of $\mathrm{CaTiO}_{3}-\mathrm{aC}$ and $\mathrm{HA}$ layer was calculated.

\section{(3) Measurement of adherence strength}

Etching of grade 2 titanium plate with $15 \times 15 \times 0.7 \mathrm{~mm}^{3}$ size was performed by boiling it in $6 \mathrm{~N} \mathrm{HCl}$ solution for 20 minutes. Then it was rinsed 3 times in distilled water. Roughness of etching surface of the titanium plate $(\mathrm{Ra})$ measured by a touch-needle type diamond surface roughness calculator was $2.5 \mathrm{~mm}$. Using 
Noriyuki Nagai et al.: Development of New Coating Material ( $\left.\mathrm{CaTiO}_{3}-\mathrm{aC}\right)$

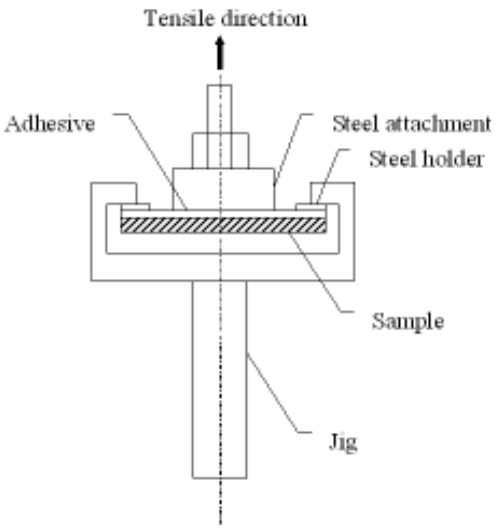

Figure 1. Model of device for pull-up strength test between titanium and coating material based on JIS A 6909:2003.

this titanium plate, first test piece of 1 layer coating with $\mathrm{CaTiO}_{3}-$ $\mathrm{aC}$ was prepared, then 1 layer of HA coating was added. At this step test piece of 2 layers with $\mathrm{CaTiO}_{3}-\mathrm{aC} / \mathrm{HA}$ coating (hereafter called as test piece of 2 layers coating) was prepared. As controls each of test pieces of 1 layer coating with $\mathrm{CaTiO}_{3}-\mathrm{aC}$ or $\mathrm{HA}$ was prepared using the same titanium plate. Adhesive strengths of film layers of these 3 test pieces were measured by a standard method (JIS A6909: 2003, architectural coating material). Coating plate was attached to steel table by 2 liquid type epoxy adhesive agent (araldite) and fixed for 24 hours at room temperature. Pull up strength test was performed at a $0.1 \mathrm{~mm} / \mathrm{min}$ of crosshead speed using universal test machine (Autograph AK-100KG, Shimadzu Co. Ltd., Tokyo, Japan)(Figure 1). The measurement was repeated 6 times.

\section{Results}

\section{Distribution state of carbon-included $\mathrm{CaTiO}_{3}-\mathrm{C}$}

At high power magnification of TEM image, granule of coated $\mathrm{CaTiO}_{3}-\mathrm{aC}$ showed micro crystal structure with diameter of 10$20 \mathrm{~nm}$. Aggregates of these micro crystals resulted in formation of multicrystals (Figure 2). Electronic diffraction data showed that crystal system of $\mathrm{CaTiO}_{3}-\mathrm{aC}$ belongs to the orthorhombic system (JCPDS-International Centre for Diffraction Data) (Figure 2 , right down inset).

At EELS analysis, type of element within $\mathrm{CaTiO}_{3}-\mathrm{aC}$ was clarified (Figure 3). Carbon (C) peak in addition to $\mathrm{Ca}$, $\mathrm{Ti}$ and $\mathrm{O}$ peaks suggested that $\mathrm{C}$ element included in $\mathrm{CaTiO}_{3}-\mathrm{aC}$ coating material (Figure 3).

At TEM image of $\mathrm{CaTiO}_{3}-\mathrm{aC}$ and element mapping with $\mathrm{EF}$ TEM as well as color mapping of these analysis, $\mathrm{C}, \mathrm{Ca}$, Ti and $\mathrm{O}$ distributions were observed (Figure 4). Though $\mathrm{Ca}, \mathrm{Ti}$ and $\mathrm{O}$ distributed in all area, $\mathrm{C}$ was localized indefinitely. Right down color mapping image also confirmed indefinite distribution of carbon (Figure 4). All these analysis indicated that $\mathrm{C}$ existed in an indefinite form within multicrystals of $\mathrm{CaTiO}_{3}-\mathrm{aC}$ coating

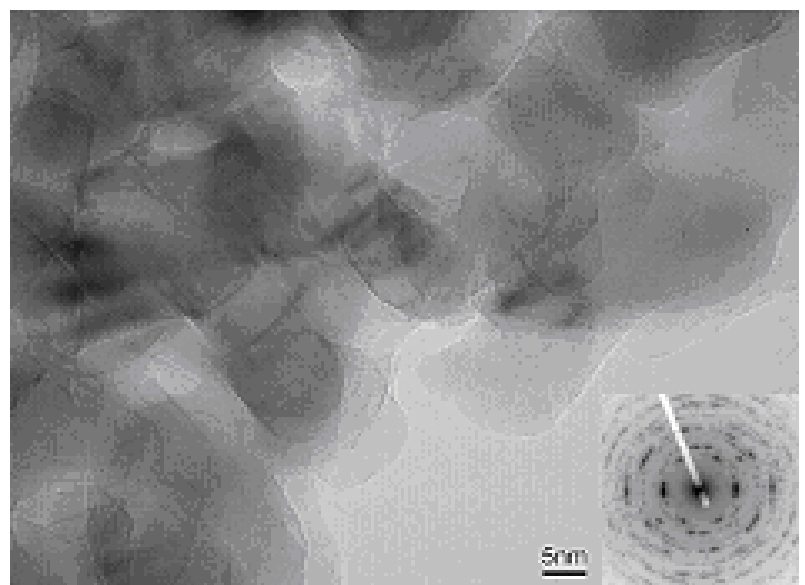

Figure 2. High-power TEM magnification image and electron diffraction pattern of $\mathrm{CaTiO}_{3}-\mathrm{aC}$ coating powder. At high-power TEM magnification image, coated $\mathrm{CaTiO}_{3}-\mathrm{aC}$ was shown as conglomerated multicrystals of clustered microcrystals. At electron diffraction pattern (right down inset), $\mathrm{CaTiO}_{3}-\mathrm{aC}$ crystal system belongs to the orthorhombic system (JCPDS-International Centre for Diffraction Data).

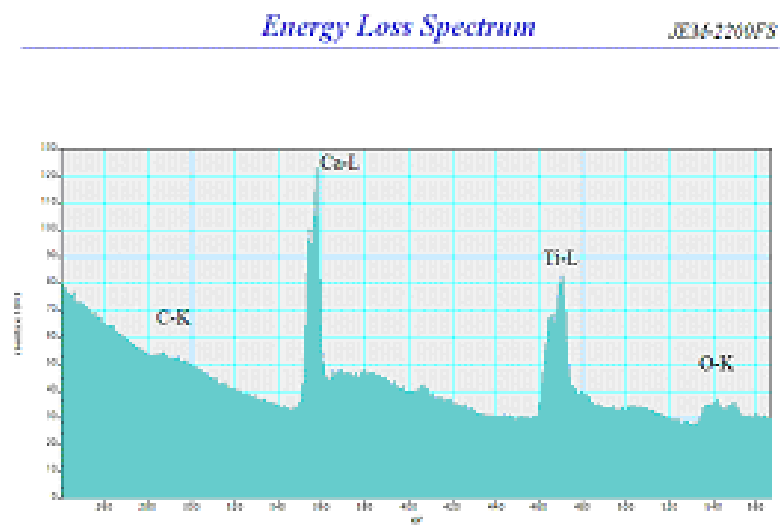

Figure 3 Element analysis of $\mathrm{CaTiO}_{3}-\mathrm{aC}$ by EELS. Carbon (C) peak in addition to $\mathrm{Ca}$, Ti and $\mathrm{O}$ peaks suggested that $\mathrm{C}$ element included in CaTiO3-aC coating material.

material.

Cross-sectional observation of 4 layers coating material and quantitative analysis of the elements at the each layer

At cross-sectional analysis of 4 layers coating material with SEM, 4 layers structure of $\mathrm{CaTiO}_{3}-\mathrm{aC} / \mathrm{HA} / \mathrm{CaTiO}_{3}-\mathrm{aC} / \mathrm{HA}$ was observed on the titanium base (Figure 5). From mass increase and theoretical density of the $\mathrm{CaTiO}_{3}\left(4.04 \mathrm{~g} / \mathrm{cm}^{3}\right)$, thickness of $\mathrm{CaTiO}_{3}-\mathrm{aC}$ film layer was calculated to be $0.6 \pm 0.1 \mathrm{ìm}$. Similarly, from mass increase and theoretical density of the HA $\left(3.16 \mathrm{~g} / \mathrm{cm}^{3}\right)$, thickness of HA film layer was calculated to be $2.4 \pm 0.4 \mathrm{ìm}$.

Next quantitative examination of $\mathrm{C}$ at $\mathrm{CaTiO}_{3}-\mathrm{aC}$ layer was performed by element analysis of each of the coated 4 layers (Figure 6, Table 1). Measurement of element ratio (atomic \%) at $\mathrm{CaTiO}_{3}-\mathrm{aC}$ layers was described as follows: As shown in composition image (reflect electron image) of figure 6, asterisk mark (*) shows irradiation center of electronic beams at EDS analysis. As shown in this image, enlargement of electron beams 


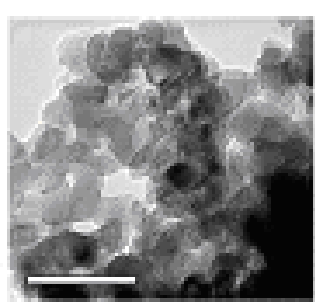

TEDI Image

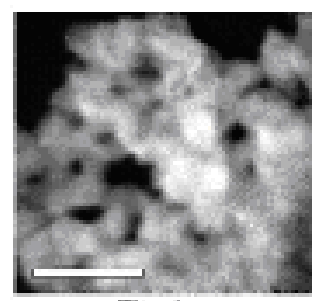

Tilanimem

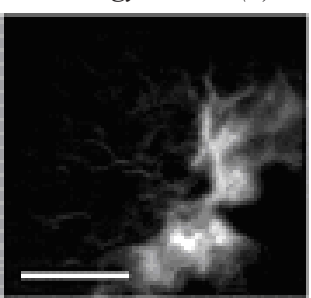

Cabon

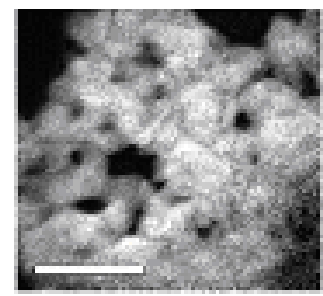

Oxygun

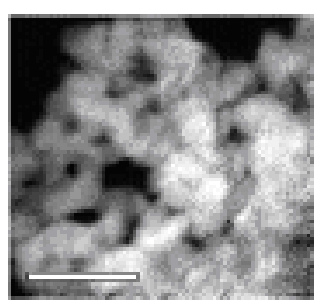

Calcium

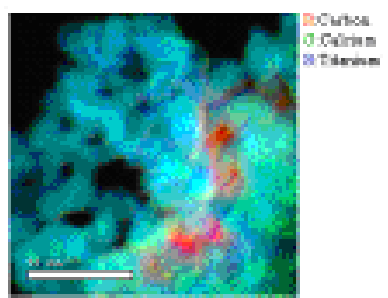

Color mapping

Figure 4 TEM image of $\mathrm{CaTiO}_{3}-\mathrm{C}$, element mapping with EF-TEM and color mapping of these elements. Though $\mathrm{Ca}$, Ti and $\mathrm{O}$ distributed in all area, $\mathrm{C}$ was localized only at some areas. Right down color mapping image also confirmed indefinite distribution of carbon. $\mathrm{C}$, red; $\mathrm{Ca}$, green; Ti, blue.

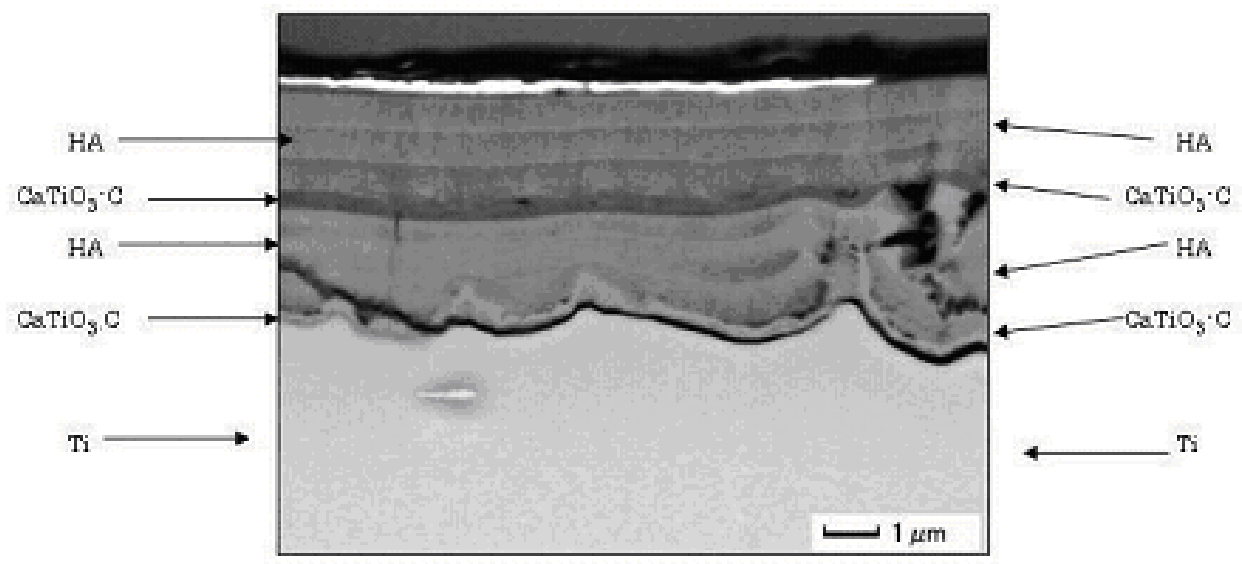

Figure 5.Cross-sectional analysis of 4 layers $\left(\mathrm{CaTiO}_{3}-\mathrm{aC} / \mathrm{HA} / \mathrm{CaTiO}_{3}-\mathrm{aC} / \mathrm{HA}\right)$ coating material (about $\left.5 \mathrm{~mm}\right)$ at titanium surface border (SEM, reflect electron image). From mass increase and theoretical density of the $\mathrm{CaTiO}_{3}$ $\left(4.04 \mathrm{~g} / \mathrm{cm}^{3}\right)$, thickness of $\mathrm{CaTiO}_{3}-\mathrm{aC}$ film layer was calculated to be $0.6 \pm 0.1 \mu \mathrm{m}$. Similarly, from mass increase and theoretical density of the HA $\left(3.16 \mathrm{~g} / \mathrm{cm}^{3}\right)$, thickness of HA film layer was calculated to be $2.4 \pm 0.4 \mathrm{im}$.

is circular with a diameter of about $1 \mathrm{~mm}$ from center of each irradiation. Because results of element analysis at each of point 040 ( $\mathrm{CaTiO}_{3}-\mathrm{aC}$ layer-second layer), point 042 (HA layer-first layer) and point 043 ( $\mathrm{CaTiO}_{3}-\mathrm{aC}$ layer-first layer) also include information from adjacent layers, pure measurement of each element ratio could not be done. Element ratio of $\mathrm{CaTiO}_{3}-\mathrm{aC}$ was considered to be calculated more precisely in the second layer of CaTiO3-aC (point 040) than in the first layer of $\mathrm{CaTiO}_{3}-\mathrm{aC}$ (point 043) because frequency of sintering of the previous one is less than the latter one. However, results of $\mathrm{Ca}, \mathrm{O}, \mathrm{P}$ and $\mathrm{C}$ element analysis were considered to consist of components of adjacent HA layer. Since Ti was not included in HA, result of Ti element analysis (8.57 atomic \%) was considered to represent only component of $\mathrm{CaTiO}_{3}-\mathrm{aC}$ layer. Because $\mathrm{C}$ should not exist at the point 045 (Ti base), the calculated value of 5.81\% was considered as background. Thus subtraction of this carbon ratio (5.81\%) from the carbon ratio of $9.67 \%$ at point 040 will give us the actual ratio of carbon $(3.86 \%)$ at this area. When similar calculations are done for $\mathrm{O}$ and $\mathrm{Ca}$, actual ratios for $\mathrm{O}(58.18-0=58.18)$ and $\mathrm{Ca}(16.48$ $0.84=15.64$ ) (atomic\%) will be obtained. From these findings, element ratios of $\mathrm{CaTiO}_{3}-\mathrm{aC}$ (atomic\%) were found to be as 15.64 for $\mathrm{Ca}, 8.57$ for Ti, 58.18 for $\mathrm{O}$, and 3.86 for C. Our results demonstrated that this novel compound consists of about 4 atomic $\%$ carbon.

Likewise as shown in table 1 , mass $\%$ of $\mathrm{C}$ at point 040 is 4.97 mass \%, and when the background level of Ti base (point 045) was subtracted from this ratio, the actual ratio was found to be 3 4 mass $\%$. 


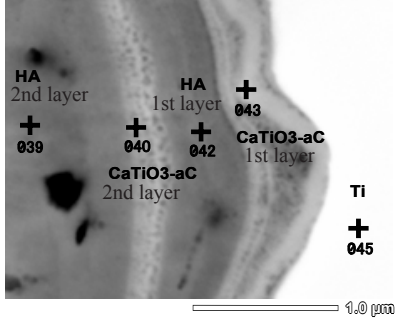

compositional image (backscattered electron image)

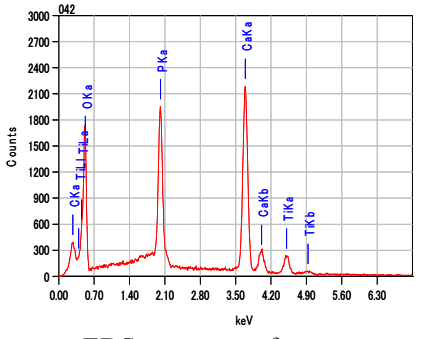

EDS spectrum of Point 042 (1st HA layer)

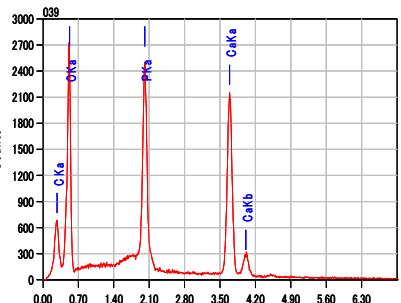

EDS spectrum of Point 039 (2nd HA layer)

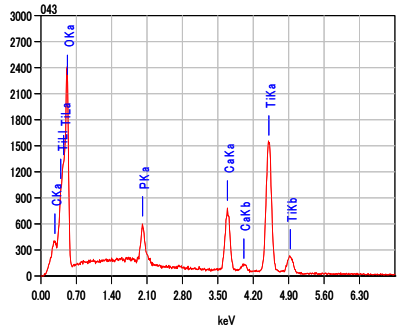

EDS spectrum of Point 045(Ti matrix)

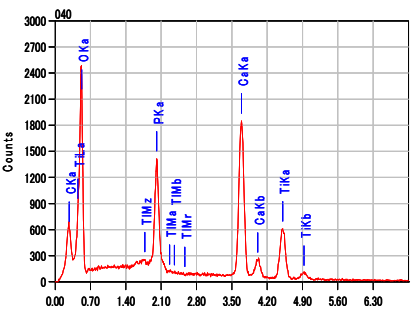

EDS spectrum of Point 040 (2nd $\mathrm{CaTiO}_{3}-\mathrm{aC}$ layer)

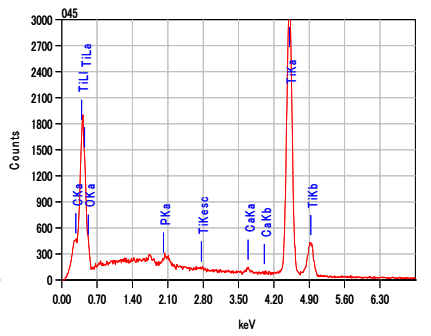

EDS spectrum of Point 043 (1st $\mathrm{CaTiO}_{3}-\mathrm{aC}$ layer)

Figure 6. Element analysis at each layer of 4 layers coating material. Element analysis by SEM+EDS. Composition image (reflect electron image). X-ray spectrum. Ti:Ti matrix containing measurement point $045, \mathrm{CaTiO}_{3}-\mathrm{aC} 1^{\text {st }}$ layer: containing measurement point $043, \mathrm{HA} 1^{\text {st }}$ layer: containing measurement point $042, \mathrm{CaTiO}_{3}$-aC 2 nd layer: containing measurement point 040 , HA 2nd layer: containing measurement point 039 .

Table 1: Density of each layer element (Figure 5,6 ) by SEM+EDS (standardless method)

\begin{tabular}{|c|c|c|c|c|c|}
\hline & $\bar{C}$ & $\mathbf{O}$ & $\mathbf{P}$ & $\mathbf{C a}$ & $\overline{\mathbf{T i}}$ \\
\hline Ti matrix & $1.53 \mathrm{mass} \%$ & 0 mass $\%$ & 0.13 mass $\%$ & 0.73 mass $\%$ & $97.61 \mathrm{mass} \%$ \\
\hline 45 & 5.81 at. $\%$ & 0 at. $\%$ & 0.19 at. $\%$ & 0.84 at. $\%$ & 93.16 at. $\%$ \\
\hline $\begin{array}{l}\mathrm{CaTiO}_{3}-\mathrm{aC} \text { layer } \\
(1 \mathrm{st}) \\
43\end{array}$ & $\begin{array}{l}1.63 \text { mass } \% \\
3.46 \text { at. } \%\end{array}$ & $\begin{array}{l}39.6 \text { mass } \% \\
63.24 \text { at. } \%\end{array}$ & $\begin{array}{l}3.01 \text { mass } \% \\
2.48 \text { at. } \%\end{array}$ & $\begin{array}{l}10.33 \text { mass } \% \\
6.59 \text { at. } \%\end{array}$ & $\begin{array}{c}45.43 \text { mass } \% \\
24.23 \text { at. } \%\end{array}$ \\
\hline $\begin{array}{l}\text { HA layer } \\
(1 \mathrm{st}) \\
42\end{array}$ & $\begin{array}{l}2.82 \text { mass } \% \\
5.82 \text { at. } \%\end{array}$ & $\begin{array}{l}34.19 \text { mass } \% \\
53.01 \text { at. } \%\end{array}$ & $\begin{array}{l}16.09 \text { mass } \% \\
12.89 \text { at. } \%\end{array}$ & $\begin{array}{l}39.51 \mathrm{mass} \% \\
24.46 \text { at. } \%\end{array}$ & $\begin{array}{c}7.39 \text { mass } \% \\
3.83 \text { at. } \%\end{array}$ \\
\hline $\begin{array}{l}\mathrm{CaTiO}_{3}-\mathrm{aC} \text { layer } \\
(2 \mathrm{nd}) \\
40\end{array}$ & $\begin{array}{l}4.97 \text { mass } \% \\
9.67 \text { at. } \%\end{array}$ & $\begin{array}{l}39.81 \mathrm{mass} \% \\
58.18 \text { at. } \%\end{array}$ & $\begin{array}{l}9.41 \mathrm{mass} \% \\
7.10 \text { at. } \%\end{array}$ & $\begin{array}{l}28.25 \text { mass } \% \\
16.48 \text { at. } \%\end{array}$ & $\begin{array}{c}17.56 \text { mass } \% \\
8.57 \text { at. } \%\end{array}$ \\
\hline $\begin{array}{l}\text { HA layer } \\
\text { (2nd) } \\
39\end{array}$ & $\begin{array}{l}6.98 \text { mass } \% \\
12.68 \text { at. } \%\end{array}$ & $\begin{array}{l}41.20 \text { mass } \% \\
56.22 \text { at. } \%\end{array}$ & $\begin{array}{l}17.94 \text { mass } \% \\
12.65 \text { at. } \%\end{array}$ & $\begin{array}{l}33.88 \text { mass } \% \\
18.45 \text { at. } \%\end{array}$ & $\begin{array}{c}0 \text { mass } \% \\
0 \text { at. } \%\end{array}$ \\
\hline
\end{tabular}

Ti :Ti (TP35), H: $<0.013, \mathrm{O}:<0.20, \mathrm{~N}:<0.05, \mathrm{Fe}:<0.25($ JIS H 4600-1979)

Density of element for ideal materials.

\begin{tabular}{|c|c|c|c|c|c|}
\hline & $\mathrm{C}$ & $\mathbf{O}$ & $\mathbf{P}$ & $\mathrm{Ca}$ & $\mathbf{T i}$ \\
\hline \multirow[t]{2}{*}{$\mathrm{CaTiO}_{3}$} & 0 mass $\%$ & 35.3 mass $\%$ & 0 mass $\%$ & 29.47 mass $\%$ & 35.23 mass $\%$ \\
\hline & 0 at. $\%$ & 60 at. $\%$ & 0 at. $\%$ & 20 at. $\%$ & 20 at. $\%$ \\
\hline \multirow[t]{2}{*}{$\mathrm{Ca}_{10}\left(\mathrm{PO}_{4}\right)_{6}(\mathrm{OH})_{2}$} & 0 mass $\%$ & $38.70 \mathrm{mass} \%$ & 17.02 mass $\%$ & $44.06 \mathrm{mass} \%$ & 0 mass $\%$ \\
\hline & 0 at. $\%$ & 56.41 at. $\%$ & 12.82 at. $\%$ & 25.64 at. $\%$ & 0 at. $\%$ \\
\hline
\end{tabular}

On the other hand, at the second HA layer (point 039), because Ti is $0 \%$, element ratio calculated at HA layer is highly likely to be pure. Thus when background of Ti base (point 045) is subtracted, element ratios are found to be 17.61 for $\mathrm{Ca}(18.45-$ 

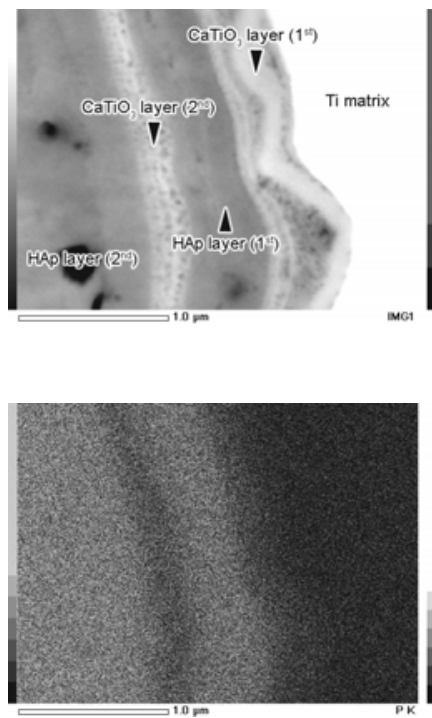

Phosphate map

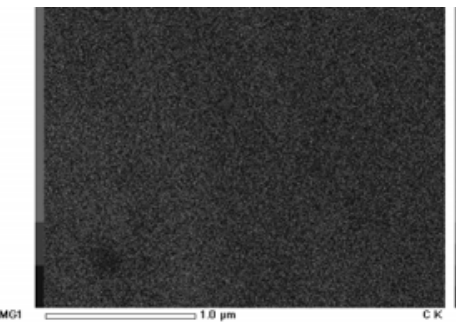

Carbon map

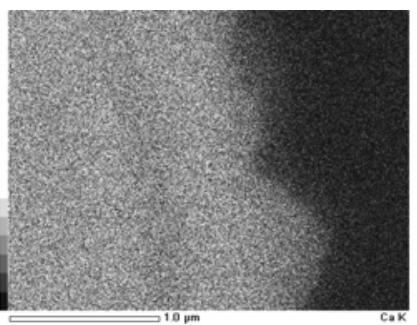

Calcium map

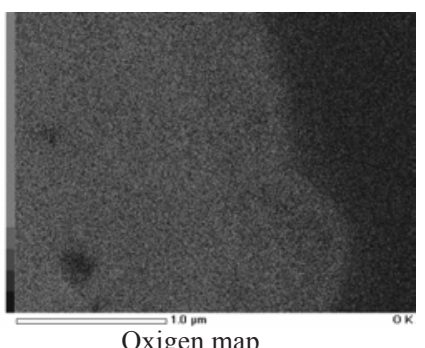

Oxigen map

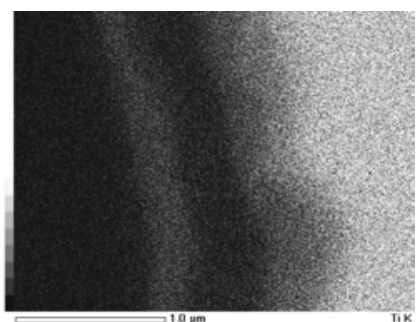

Titanium map

Figure 7. EDS analysis at 4 layers coating. Existence of high-density carbon at $\mathrm{CaTiO}_{3}-\mathrm{aC}$ layer was confirmed.

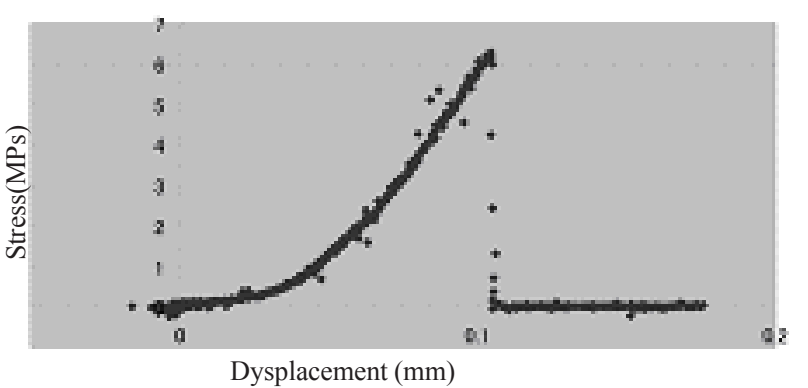

Figure 8. Stress curve plot of pull up strength test of 1 layer $\mathrm{CaTiO}_{3}-\mathrm{aC}$ coating.

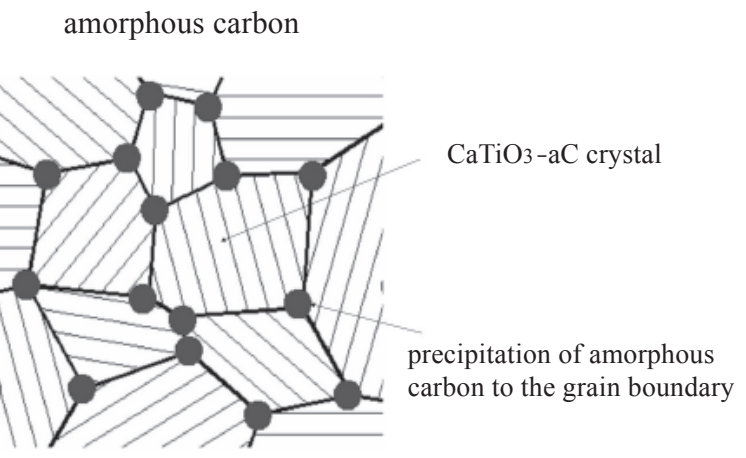

Figure 9. Expected structure of $\mathrm{CaTiO}_{3}-\mathrm{aC}$ complex

$0.84), 12.46$ for $\mathrm{P}$ (12.65-0.19), 56.22 for O (56.22-0), and 6.87 for $\mathrm{C}(12.68-5.81)$ atomic\%). This result suggests that HA prepared by the current method includes a large quantity of carbon and possesses characteristics of carbonate apatite.

Moreover at cross-sectional image, EDS analysis showed that though $\mathrm{P}$ at $\mathrm{CaTiO}_{3}-\mathrm{aC}$ layer decreased, peaks of $\mathrm{Ca}$, Ti and $\mathrm{O}$
Table 2. Adhesive strength between the coating and titanium Sample: 1 layer coated $\mathrm{CaTiO}_{3}-\mathrm{C}$, 2 layer coated $\mathrm{CaTiO}_{3}-\mathrm{C} / \mathrm{HA}, 1$ layer coated HA. Adhesive strength (MPa), Surface roughness (Ra).

\begin{tabular}{lrcc}
\hline \multicolumn{1}{c}{ Sample } & \multicolumn{1}{c}{$\begin{array}{c}\text { Adhesive } \\
\text { strength }(\mathrm{MPa})\end{array}$} & $\begin{array}{l}\text { Surface } \\
\text { roughness( (Ra) }\end{array}$ \\
\hline $\mathrm{CaTiO}_{3}-\mathrm{C}$, & 1 Layer Coating & $6.3 \pm 0.7$ & $2.5 \pm 0.5$ \\
$\mathrm{CaTiO}_{3}-\mathrm{C} / \mathrm{HA}$, & 2 Layer Coating & $4.9 \pm 0.6$ & $2.5 \pm 0.5$ \\
$\mathrm{HA}$ & 1 Layer Coating & $2.0 \pm 0.4$ & $2.5 \pm 0.5$ \\
\hline
\end{tabular}

were high, and the layer of $\mathrm{CaTiO}_{3}-\mathrm{aC}$ interpositioned between the inside and outside HA layers consisted of high density carbon (Figure 7).

\section{Adherence strength of Ti base and coating materials}

From result of pull up strength test of 1 layer $\mathrm{CaTiO}_{3}-\mathrm{aC}$ coating method, stress curve plotted is shown in figure 8. Results of adhesive strength test between each coating layer and Ti base material were found to be 3 times higher for $\mathrm{CaTiO}_{3}-\mathrm{aC}$ alone (6.3 MPa) and 2.5 times stronger for $\mathrm{CaTiO}_{3}-\mathrm{aC}$-interpositioned HA coating (4.9 MPa) as compared to HA coating alone (2.0 MPa) (Table 2). This result suggests that $\mathrm{CaTiO}_{3}-\mathrm{aC}$ functions for improvement of the adhesive strength between Ti and HA.

\section{Discussion}

\section{Characteristics of titanium coating material ( $\left.\mathrm{CaTiO}_{3}-\mathrm{CC}\right)$} prepared by modified thermal decomposition method

Recently perovskite $\left(\mathrm{CaTiO}_{3}\right)$ and similar materials have been paid attention due to their use as an adhesive substrate for titanium coating material ${ }^{6,10)}$, as well as their novel biomaterial characteristics with high bone conductivity ability ${ }^{16-20)}$. And 
Noriyuki Nagai et al.: Development of New Coating Material (CaTiO3-aC)

development of an insoluble HA coating method instead of plasmasprayed coating has been rushed. Within $\mathrm{CaTiO}_{3}$ coating method, only $50 \mathrm{~nm}$ of ultra-thin layer can be done by ion sputtering ${ }^{17-20)}$, and thus regarding with absence/presence of bone conductivity, opinions are not constant. Therefore thermal decomposition method took attention of the researchers ${ }^{6}$.

In this study, we developed a modified thermal decomposition method for $\mathrm{HA}$ and $\mathrm{CaTiO}_{3}$ coating. This modification resulted in formation of a novel compound $\left(\mathrm{CaTiO}_{3}-\mathrm{aC}\right)$ for the coating, which consists of carbon in addition to perovskite $\left(\mathrm{CaTiO}_{3}\right)$. Our results clarified the following facts:

(1) Thickness of $\mathrm{CaTiO}_{3}-\mathrm{aC}(0.6 \pm 0.1 \mu \mathrm{m})$ and $\mathrm{HA}(2.4 \pm 0.4 \mu \mathrm{m}$ ) layers is extremely thin.

(2) Since $\mathrm{CaTiO}_{3}-\mathrm{aC}$ is composed of granules with a size of 10$20 \mathrm{~nm}$ and the carbon is indefinitely localized, the carbon was considered to be in an amorphous state.

(3) Content of amorphous carbon within $\mathrm{CaTiO}_{3}-\mathrm{aC}$ coating is about $4 \mathrm{~mol} \%$. Besides HA layer also consists of carbon. Thus HA layer was considered to have characteristics of carbonate apatite.

(4) When $\mathrm{CaTiO}_{3}-\mathrm{aC}$ was used as a bonding material between titanium and HA, the adhesive strength was 3 times stronger as compared to HA alone coating.

Furthermore our group has also examined physicochemical analysis and bone conductivity of the novel material.

According to study of Okauchi et al. (preparation in press), following facts were clarified: Both $\mathrm{CaTiO}_{3}-\mathrm{Ca}$ and $\mathrm{HA}$ was found to have minus charge; (2) Solubility of $\mathrm{CaTiO}_{3}-\mathrm{aC}$ was $1 / 10$ of HA.

Likewise, according to study of Andrea et al. (unpublished data) and Inoue et al. (preparation in press), no cytotoxicity of $\mathrm{CaTiO}_{3}-\mathrm{aC}$ was detected. And following facts were made clear: (1) $\mathrm{CaTiO}_{3}-\mathrm{aC}$ had similar level of bone conductivity with HA; (2) $\mathrm{CaTiO}_{3}-\mathrm{aC}$ was involved in calcification reaction in appropriate cellular environment.

Moreover, Zhou and Akao showed that pore of titanium plate coated with double layer of $\mathrm{CaTiO}_{3}$ and $\mathrm{HA}$ by thermal decomposition method had similar bone binding power as compared to HA only coating in an animal study ${ }^{6}$.

All these studies and our current data suggest that $\mathrm{CaTiO}_{3}-\mathrm{aC}$ prepared by modified thermal decomposition method is an excellent material for using both as implant coating or adhesive material for HA coating.

Zhou and Akao reported for the first time coating method of perovskite $\left(\mathrm{CaTiO}_{3}\right)$ and $\mathrm{HA}^{6}$. Calcium titanate generally known as perovskite $\left(\mathrm{CaTiO}_{3}\right)$ has a cancellus cuboidal crystal structure. Within this crystal structure, 1 calcium ion at the center, 8 titanium ions at the peak and 12 oxygen ions mainly at the periphery are located. Though it is prepared as particular form by sintering with dry method at $1200{ }^{\circ} \mathrm{C}$, it has been known that it cannot be made as film type and does not contain carbon. Therefore, we considered that $\mathrm{CaTiO}_{3}$ coating material at the current study should not be called as perovskite. Rather synthesis of a novel compound named as $\mathrm{CaTiO}_{3}-\mathrm{aC}$ was suggested.

Mechanism for improvement of adhesive strength at the border of titanium and $\mathrm{CaTiO}_{3}-\mathrm{aC}$ remains unknown at this point. Generally it has been known that the higher the energy at metal surface, the better wetness with liquid occurs. Carbon has been reported to increase this surface energy ${ }^{15)}$. And both metal and carbon are hydrophobic and shows good concordance. Therefore, one possible explanation for higher adherence strength of $\mathrm{CaTiO}_{3}-$ aC-interpositioned HA coated titanium than HA alone-coated titanium in adherence strength test could be increased adhesion due to enhanced wetness depending on carbon presence.

What kind of form does carbon have within $\mathrm{CaTiO}_{3}-\mathrm{aC}$ compound? Our analysis showed that carbon existed in an indefinite form within $\mathrm{CaTiO}_{3}$ crystal. The carbon atom was suggested to be in amorphous state without crystallizing (Figure 9).

\section{Differences between modified thermal decomposition and general thermal decomposition methods}

In conventional thermal decomposition method, a solution with equal $\mathrm{Ca}$ / Ti composition ratio (1) in $\mathrm{CaTiO}_{3}$ solution of the material is prepared. Using this ratio, only $\mathrm{CaTiO}_{3}$ can be formed, and amorphous carbon does not exist. In our modified thermal decomposition method, $\mathrm{Ca} / \mathrm{Ti}$ ratio in the solution was kept between 1.01 1.10. Thus more $\mathrm{Ca}$ in the solution had reaction with $\mathrm{TiO}_{2}$, and plenty of nano-level calcium titanate-amorphous carbon $\left(\mathrm{CaTiO}_{3}-\mathrm{aC}\right)$ was generated by sintering.

On the other hand, $\mathrm{Ca} / \mathrm{P}$ was mixed within HA solution of the material with a theoretical ratio of 1.67. When this ratio was used, in plasma-sprayed method (high temperature), $\mathrm{CaO}$ and $\alpha$-TCP included HA is synthesized. Thus this formation was considered to advance resorption of HA. However, in our modified method, $\mathrm{Ca} / \mathrm{P}$ ratio was prepared in a range between $1.75 \sim 1.85$. In this case, as reported by Zhou and $\mathrm{Akao}^{6}$, about $30 \%$ of $\beta$-TCP included $\mathrm{HA}$ is synthesized, and $\mathrm{CO}_{3}$ replaces with $\mathrm{PO}_{4}$, which then results in formation of a small quantity of carbonate apatite. Generally hydroxyapatite in the body has been known to contain low resorptive $\beta$-TCP rather than small quantity of carbonate apatite or $\alpha$-TCP. According to comparative experiment of the HA solubility sintering at $650^{\circ} \mathrm{C}$ and $1200^{\circ} \mathrm{C}$ by Okauchi et al (unpublished data), solubility of HA sintered at $650{ }^{\circ} \mathrm{C}$ was lower as compared to its sintering at $1200^{\circ} \mathrm{C}$. Moreover solubility of $\mathrm{CaTiO}_{3}-\mathrm{aC}$ as compared to $\mathrm{HA}$ both sintered at $650 \mathrm{CaTiO}_{3}-\mathrm{aC}$ was lower. Thus these results suggest that resorption of 2 layers of $\mathrm{CaTiO}_{3}-\mathrm{aC} / \mathrm{HA}$ in the body is late, and the bone conductivity is expected to be kept for a long period.

In the current modified thermal decomposition method, the sintering temperature was limited to $650{ }^{\circ} \mathrm{C}$. At temperatures less than $500{ }^{\circ} \mathrm{C}$, generation of $\mathrm{CO}_{2}$ becomes easy, and $\mathrm{CaCO}_{3}$ is 
formed, which decreases crystallization and then bonding ability of HA. At high temperatures, titanium base has been known to become fragile ${ }^{17-20)}$. Moreover, in the current modified method, a rapid heating $\left(20-200{ }^{\circ} \mathrm{C} /\right.$ minute $)$ was made as an absolute condition. Due to rapid heating, $\mathrm{O}_{2}$ supply will not be enough, which gives rise to incomplete burning. Thus carbon within the organic solvent will remain in $\mathrm{CaTiO}_{3}$ crystal in an amorphous state. As mentioned above, this amorphous carbon was considered to improve wetness at Ti surface border and contribute to increase of adhesive strength between $\mathrm{Ti}$ and HA.

In conclusion, the novel developed coating material $\left(\mathrm{CaTiO}_{3}-\right.$ aC) can be used for various purposes such as titanium implant coating substrate or by itself as a new biomaterial.

\section{Acknowledments}

This work was supported by Grant-in-Aid for Scientific Research(B) (17406027) and (C) (19592236) from the Japan Society for the Promotion of Science.

\section{References}

1. Fujishiro Y, Sato N, Uchida S, Sato T. Coating of CaTiO3 on titanium substrates by hydrothermal reactions using calciumethylene diamine tetra acetic acid chelate. J Mater Sci Mater Med 9(7):363-367, 1998

2. Orly I, Gregoire M, Menanteau J, Heughebaert M, Kerebel B. Chemical changes in hydroxyapatite biomaterial under in vivo and in vitro biological conditions. Calcif Tissue Int 45(1):20-26, 1989

3. Daculsi G, LeGeros RZ, Deudon C. Scanning and transmission electron microscopy, and electron probe analysis of the interface between implants and host bone. Osseo-coalescence versus osseo-integration. Scanning Microsc 4(2):309-314, 1990

4. de Bruijn JD, Klein CP, de Groot K, van Blitterswijk CA. The ultrastructure of the bone-hydroxyapatite interface in vitro. J Biomed Mater Res 26(10):1356-1382, 1992

5. Webster TJ, Ergun C, Doremus RH, Lanford WA. Increased osteoblast adhesion on titanium-coated hydroxylapatite that forms CaTiO3. J Biomed Mater Res A 67(3):975-980, 2003

6. Zhou P, Akao M. Preparation and characterization of double layered coating composed of hydroxyapatite and perovskite by thermal decomposition. Biomed Mater Eng 7(1):67-81, 1997

7. de Groot K, Geesink RGT, Serekin P. Plasma sprayed coatings of hydroxyapatite. J Biomed Mater Res 21:1375-1381, 1987
8. Radin SR, Ducheyne P. Plasma spraying induced changes of calcium phosphate ceramic characteristics and the effect on in vitro stability. J Mater Sci Mater Med 3:33-42, 1992

9. Ellies LG, Nelson DGA, Featherstone JDB. Crystallographic changes in calcium phosphates during plasma-spraying. Biomaterials 13:313-316, 1992

10. Ukegawa Y. Pull-out strength and bone tissue reaction of plasma-sprayed hydroxyapatite coatings with different thickness or substrates. J Jpn Orthop Assoc 66:688-702, 1992

11. A. K. Lynn and D. L. DuQuesnay. Hydroxyapatite-coated $\mathrm{Ti} \cdot \mathrm{EA} 1 \cdot \mathrm{EV}$ Part 1: the effect of coating thickness on mechanical fatigue behavior. Biomaterials 23(9):1937-1946, 2002

12. Hasegawa S. Characterization and canine bone tissue reaction of hydroxyapatite-coated titanium using thermal decomposition method. Bull Tokyo Med Dent Univ 43(1):2544, 1996

13 Lin JH, Liu ML, Ju CP. Morphologic variation in plasmasprayed hydroxyapatite-bioactive glass composite coatings in Hank's solution. J Biomed Mater Res 28(6):723-30, 1994

14. Kweh SW, Khor KA, Cheang P. High temperature in-situ XRD of plasma sprayed HA coatings. Biomaterials 23(2):381387,2002

15. Kilpadi DV, Lemons JE, Liu J, Raikar GN, Weimer JJ, Vohra Y. Cleaning and heat-treatment effects on unalloyed titanium implant surfaces. Int J Oral Maxillofac Implants 15(2):219230, 2000

16. Ohtsu N, Sato K, Saito K, Yanagawa A, Saito K, Imai, Kohgo T, Yokoyama A, Asami K, Hanawa T. CaTiO3 coating on titanium for biomaterial application?-?Optimum thickness and tissue response. J Biomed Mater Res A 82(2):304-315, 2007

17. Ohtsu N, Sato K, Saito K, Asami K, Hanawa T. Calcium phosphates formation on $\mathrm{CaTiO} 3$ coated titanium. J Mater Sci Mater Med 18:1009•E016, 2007

18. Wang CK, Lin JH, Ju CP, Ong HC, Chang RP. Structural characterization of pulsed laser-deposited hydroxyapatite film on titanium substrate. Biomaterials 18(20):1331-1338, 1997

19. Ohtsuka Y, Matsuura M, Chida N, Yoshinari M, Sumii T, Derand T. Formation of hydroxyapatite coating on pure titanium substrates by ion beam dynamic mixing. Surface Coating Technol 65:224-230, 1994

20. Brossa F, Cigada A, Chiesa R, Paracchini L, Consonni C. Adhesion properties of plasma sprayed hydroxyapatite coatings for orthopedic prostheses. Bio-Med Mater Eng 3:127136,1993 